\title{
SOCIALLY RESPOSIBLE INVESTING (SRI) DAN KINERJA SAHAM
}

\author{
Heriyanto \\ Program Studi Manajemen Fakultas Bisnis dan Akuntansi \\ Universitas Katolik Musi Charitas, Palembang, Indonesia \\ heriyanto@ukmc.ac.id \\ Suramaya Suci Kewal \\ Program Studi Manajemen Fakultas Bisnis dan Akuntansi \\ Universitas Katolik Musi Charitas, Palembang, Indonesia \\ suramaya@ukmc.ac.id \\ Yohanes Andri Putranto Bernadus \\ Program Studi Akuntansi Fakultas Bisnis dan Akuntansi \\ Universitas Katolik Musi Charitas, Palembang, Indonesia \\ andri@ukmc.ac.id
}

\begin{abstract}
Abstrak: Socially Resposible Investing (SRI) dan Kinerja Saham Penelitian ini bertujuan ingin menguji secara empiris perbedaan kinerja saham berdasarkan nilai return dan risiko dari perusahaan-perusahaan yang melakukan Social Responsibility Investment (SRI) melalui perhitungan indeks SRI-KEHATI dan Jakarta Islamic Index (JII) dengan Indeks Harga Saham Gabungan (IHSG).Periode pengamatan dalam penelitian iniselama 7 tahun yaitu dari tahun 2010 sampai dengan tahun 2016. Pengujian hipotesis dilakukan dengan teknik analisa yaitu independent sample t-test dengan menggunakan tingkat signifikansi sebesar 5\%. Hasil yang diperoleh dari pengujian perbedaan return adalah tidak terdapat perbedaan antara return IHSG dengan return JII, return IHSG dengan return SRI-KEHATI, dan return JII dengan return SRIKEHATI. Hasil yang diperoleh dari pengujian perbedaan risiko adalah terdapat perbedaan risiko antara risiko IHSG dengan risiko JII, risiko IHSG dengan risiko SRI-KEHATI, dan tidak ditemukan perbedaan antara risiko JII dengan risiko SRI-KEHATI.
\end{abstract}

Kata kunci : socially responsible investing, kinerja saham.

Abstract: Socially Resposible Investing (SRI) and Stock Performance The aim of this research is to empirically test the difference between stock performance based on return and risk value of firms implementing Social Responsibility Investment (SRI) by calculating SRIKEHATI index, Jakarta Islamic Index (JII), and Composite Stock Price Index (IHSG). Observation period of this research was conducted for 7 years, from 2010 until 2016. Hypothesis testing was tested by analytical technique, independent sample t-test which using $5 \%$ as significance level. The results obtained from the difference test of return showed that there is no difference between IHSG return with JII return, IHSG return with SRI-KEHATI Index return, and JII return with SRI-KEHATI Index return. The results obtained from the difference test of risk are showed that there are differences between JCI risk and SRI-KEHATI Index risk, yet there is no difference between JII risk and SRI-KEHATI Index risk.

Keywords : socially responsible investing, stock performance. 
PENDAHULUAN

Socially Responsibe Investing (SRI)

merupakan salah satu topik yang sedang marak saat ini. SRI merupakan strategi berinvestasi dimana investor melakukan screening portofolio mereka untuk menghindari perusahaan yang tidak mendukung pengembangan lingkungan, moral, etika, agama, dan nilai sosial. SRI berbeda dari strategi berinvestasi secara konvensional karena tujuan investor melakukan strategi berinvestasi berdasarkan konsep SRI adalah mendapatkan dua tipe return, yaitu dari sisi keuangan dan sosial.

Pasar modal Indonesia sudah mulai melakukan screening terhadap perusahaan yang menjalankan Socially Responsible Investing (SRI), terbukti dengan dibentuknya indeks harga saham yang diberi nama Indeks SRI-KEHATI pada tahun 2009. Indeks SRI-KEHATI dibentuk oleh PT. Bursa Efek Indonesia bekerja sama dengan Yayasan Keanekaragaman Hayati Indonesia (Yayasan KEHATI). Indeks ini dimaksudkan untuk memberi tambahan pedoman investasi bagi investor dan memberi dorongan bagi emiten yang memiliki kinerja yang sangat baik agar selalu melakukan usaha-usaha berkelanjutan, serta memiliki kesadaran terhadap lingkungan hidup, sosial dan tata kelola perusahaan yang baik. Selain Indeks SRI-KEHATI, juga terdapat Jakarta
Islamic Indeks (JII) yang dibentuk pada tahun 2000 dimana PT. Bursa Efek Indonesia bekerja sama dengan PT. Danareksa Investment Management. Saham-saham yang termasuk dalam JII merupakan saham yang sesuai dengan syariah Islam dimana perusahaanperusahaan tersebut dilarang melakukan usaha perjudian dan permainan yang tergolong judi atau perdagangan yang dilarang, dilarang menyelenggarakan jasa keuangan jasa keuangan yang menerapkan konsep ribawi, jual beli resiko yang mengandung gharar dan maysir, dilarang memproduksi, mendistribusikan, memperdagangkan dan atau menyediakan : barang dan atau jasa yang haram karena zatnya (haram li-dzatihi), barang dan atau jasa yang haram bukan karena zatnya (haram li-ghairihi) yang ditetapkan oleh DSN-MUI, dan atau barang dan atau jasa yang merusak moral dan bersifat mudarat. Perusahaan juga dilarang melakukan investasi pada perusahaan yang pada saat transaksi, tingkat (nisbah) hutang perusahaan kepada lembaga keuangan ribawi lebih dominan dari modalnya, kecuali investasi tersebut dinyatakan kesyariahannya oleh DSN-MUI.

Emiten saat ini dituntut untuk melakukan Corporate Social Responsibility (CSR). Menurut World Business Council for Sustainable Development (WBCSD), Corporate Social Responsibility (CSR) 
merupakan komitmen berkelanjutan oleh dunia usaha untuk bertindak etis dan memberikan kontribusi kepada pengembangan ekonomi dari komunitas setempat ataupun masyarakat luas, bersamaan dengan peningkatan taraf hidup pekerjanya beserta seluruh keluarganya. Implementasi SRI membuat perusahaan menyisihkan dana perusahaan untuk digunakan dalam kegiatan CSR, tetapi di sisi lain kegiatan CSR dapat meningkatkan reputasi perusahaan di masyarakat yang pada akhirnya dapat meningkatkan nilai perusahaan tersebut. Perubahan nilai perusahaan dapat diukur dengan terjadinya perubahan harga saham perusahaan yang tercermin dalam return dan risiko perusahaan.

Tabel 1 menunjukkan return dan risiko dari SRI-KEHATI, IHSG, dan JII pada periode pengamatan tahun 2011 sampai 2016. Return tertinggi diperoleh oleh indeks SRI-KEHATI (lebih tinggi dari return IHSG) dan return terendah pada return JII. Pada sisi risiko, menunjukkan risiko dari indeks SRI-KEHATI lebih rendah dibandingkan risiko IHSG dan risiko terendah terjadi pada risiko JII. Hal ini mengindikasikan bahwa memang saham yang termasuk dalam indeks SRI-KEHATI, yang merupakan saham yang menjalankan Socially Responsibility Investment, memberikan return di atas rata-rata dengan risiko yang relatif rendah.
Tabel 1

Return dan Standar DeviasiTahunan IHSG, JII, dan SRI-KEHATI

\begin{tabular}{|c|c|c|c|}
\hline Tahun & IHSG & $\begin{array}{c}\text { SRI- } \\
\text { KEHATI }\end{array}$ & JII \\
\hline 2011 & $21,92 \%$ & $13,21 \%$ & $9,37 \%$ \\
\hline 2012 & $10,04 \%$ & $12,43 \%$ & $10,60 \%$ \\
\hline 2013 & $11,98 \%$ & $14,32 \%$ & $8,85 \%$ \\
\hline 2014 & $6,94 \%$ & $10,68 \%$ & $5,63 \%$ \\
\hline 2015 & $-0,08 \%$ & $3,00 \%$ & $-1,31 \%$ \\
\hline 2016 & $2,49 \%$ & $4,05 \%$ & $4,78 \%$ \\
\hline $\begin{array}{c}\text { Rata- } \\
\text { rata } \\
\text { Return }\end{array}$ & $8,88 \%$ & $9,62 \%$ & $6,32 \%$ \\
\hline $\begin{array}{c}\text { Standar } \\
\text { deviasi }\end{array}$ & $7,82 \%$ & $4,88 \%$ & $4,36 \%$ \\
\hline
\end{tabular}

Sumber : data sekunder diolah

Penelitian terdahulu yang membahas Social Responsibility Investing (SRI) terutama Corporate Social Responsibility (CSR) sudah pernah dilakukan. Wang (2011) melakukan penelitian yang berjudul Corporate Social Responsibility and Stock Performance (Evidence from Taiwan), menemukan bahwa kelengkapan pengungkapan CSR perusahaan memiliki pengaruh yang signifikan terhadap kinerja saham. Implikasi dari penelitian tersebut yaitu bahwa perusahaan dapat melakukan tata kelola yang baik disertai dengan peningkatan kemakmuran pemegang saham. Penelitian Diaz (2016) yang berjudul Return and Volatility Performance Comparison of Ethical and Non-Ethical Publicly-listed Financial Services Company, menemukan bahwa perusahaan keuangan yang masuk dalam kategori 


\section{JURNAL NOMINAL / VOLUME VIII NOMOR 2 / TAHUN 2019}

"ethical financial companies" pada umumnya memiliki return yang lebih besar dengan volatilitas yang lebih rendah dibandingkan perusahaan yang tidak masuk dalam kategori "ethical financial companies".

Sementara itu, beberapa penelitian lainnya yang meneliti mengenai hubungan konsep investasi perusahaan berdasarkan SRI (atau ethical stock) dan kinerja saham menemukan bahwa tidak terdapat hubungan yang signifikan di antara kedua variabel tersebut. Bratenius dan Melin (2015) melakukan penelitian yang berjudul The Impact of CSR on Financial Performance, menemukan bahwa perusahaan-perusahaan yang mendapat peringkat teratas dalam penilaian CSR tidak mempengaruhi (berdampak) pada return saham perusahaan, sedangkan yang mendapat peringkat terbawah berpengaruh secara negatif terhadap return saham. Randina dan Fachrizal (2016) dalam penelitiannya yang berjudul Perbandingan Kinerja Keuangan, Abnormal Return Dan Volume Perdagangan Saham Antara Periode Sebelum Dan Sesudah Meraih Indonesia Sustainability Reporting Award (ISRA), mendapatkan hasil bahwa tidak terdapat perbedaan abnormal return sebelum dan sesudah pengumuman ISRA.

Bedasarkan uraian di atas, terlihat bahwa hasil penelitian mengenai hubungan investasi perusahaan berkonsep SRI dan kinerja saham perusahaan masih menunjukkan hasil yang beragam (inkonsisten). Penelitian ini ingin menguji perbedaan return dan risiko perusahaanperusahaan yang termasuk dalam indeks konvensional (IHSG) dengan perusahaanperusahaan yang termasuk dalam indeks SRI-KEHATI dan JII (sebagai indikator investasi berdasarkan konsep SRI) yang ada di Bursa Efek Indonesia.

\section{KAJIAN LITERATUR Socially Responsibility Investing (SRI)}

Seperti halnya keuangan Islam, SRI berakar pada doktrin agama, dan secara spesifik tujuan yang ingin ditempuh oleh praktisi dari banyak agama agar menggunakan uang mereka dengan cara yang sesuai dengan kepercayaan mereka. Teologi Kristen pada budaya Barat mencakup fokus pada tanggung jawab moral individu untuk menggunakan uang yang sesuai dengan iman seseorang. Demikian pula, bagian-bagian pendukung Talmud Yahudi menggunakan investasi untuk mempromosikan kegiatan etis dan mencapai kebaikan sosial (Biema, 2008 dalam Bennett dan Iqbal 2013). Konteks agama ini telah mempengaruhi keputusan investasi individu selama berabad-abad. Contoh awal dari jenis kegiatan proto-SRI ini meliputi penolakan kelompok agama tertentu untuk mendukung industri yang melakukan kegiatan "berdosa", seperti 
perdagangan budak, atau untuk perdagangan produk yang dilihat sebagai "berdosa," seperti perdagangan senjata api atau alkohol.

Pada tahun 1960-an dan 1970-an, konsep investasi SRI mulai berkembang melampaui konteks keagamaan yang begitu eksplisit untuk mencakup berbagai tujuan. Tujuan ini sering diungkapkan dalam bentuk boikot investasi. Upaya semacam itu pada umumnya terfokus pada satu isu dan didorong oleh keinginan untuk mencapai tujuan politik yang spesifik. Baru beberapa dasawarsa terakhir ini, konsep investasi SRI telah berkembang melampaui fokus isu tunggal dan dikenali sebagai strategi investasi yang komprehensif dengan sendirinya. Investor yang menggunakan konsep investasi SRI sekarang memasukkan sejumlah besar manajer aset, dana pensiun, wakaf universitas, yayasan, lembaga keagamaan dan investor perorangan. Jenis isu yang menjadi perhatian investor SRI meliputi hak asasi manusia, hubungan kerja, praktik lingkungan dan tata kelola perusahaan. Beberapa investor SRI fokus pada salah satu masalah, sementara yang lain memperhitungkan berbagai masalah tersebut. Dalam membuat keputusan investasi, investor ini melakukan analisis kualitatif terhadap kebijakan atau praktik perusahaan di area spesifik atau area yang menjadi perhatian investor terhadap analisis kuantitatif atas kondisi dan prospek keuangan perusahaan mereka. Beberapa investor menerapkan strategi SRI tersebut ke keseluruhan portofolio mereka, sementara yang lain menggunakan strategi SRI hanya dengan memperhatikan segmen atau portofolio tertentu dari sebagian aset mereka yang dikelola.

Secara tradisional, jenis strategi yang paling umum digunakan oleh investor SRI disebut sebagai "negative screening" yaitu tidak membeli sekuritas yang dikeluarkan oleh perusahaan yang gagal memenuhi standar investor di wilayah tertentu. Jenis perusahaan yang dikecualikan oleh "negative screening" biasanya mencakup pihak-pihak yang terlibat dalam pembuatan tembakau atau alkohol, serta operator kasino, kontraktor pertahanan dan perusahaan dengan catatan lingkungan yang buruk. Namun, selama dasawarsa terakhir, investor SRI mulai lebih aktif menggunakan teknik "positive screening" yaitu teknik yang secara aktif mencari perusahaan investasi yang menurut pertimbangan investor memiliki dampak (manfaat) sosial atau lingkungan yang menguntungkan. Filosofi SRI yang lebih proaktif ini sering disebut sebagai "impact investing".(Bennett dan Iqbal, 2013)

\section{Relevansi Islamic Financial dengan SRI}

Konsep pembangunan dalam Islam memiliki tiga dimensi: pengembangan diri individu, perkembangan fisik bumi, dan 


\section{JURNAL NOMINAL / VOLUME VIII NOMOR 2 / TAHUN 2019}

perkembangan kolektivitas manusia yang meliputi keduanya. Dalam perspektif Islam, ketiga dimensi pembangunan tersebut memberikan tanggung jawab yang berat pada individu dan masyarakat, dengan keduanya bertanggung jawab atas kekurangan pembangunan. Perkembangan yang seimbang didefinisikan sebagai kemajuan yang seimbang dalam ketiga dimensi (Abbas dan Askari, 2010 dalam Bennett dan Iqbal, 2013). Hal ini seharusnya bisa dicapai dengan mengikuti tujuan dari ajaran-ajaran Hukum Islam yang biasa disebut maqasid-e-syariah yang meliputi tujuan melestarikan kepentingan umum (maslahah). Tujuan syariah adalah untuk mempromosikan kesejahteraan semua umat manusia, yang terletak pada pengamanan iman mereka, nafs mereka, intelek mereka ( $a q l$ ), keturunan mereka (nasl) dan kekayaan mereka (mal). Apapun yang menjamin perlindungan kelima komponen ini melayani kepentingan umum dan diinginkan (Dusuki dan Abdullah, 2007 dalam Bennett dan Iqbal, 2013).

Sistem ekonomi dan keuangan yang didorong oleh mandat sosial-kesejahteraan dan tanggung jawab sosial akan menghasilkan transaksi keuangan dan transaksi dengan pelestarian nilai-nilai sosial yang ada. Namun, fitur instrumen keuangan syariah ini juga harus menarik bagi investor di pasar SRI konvensional.

Industri keuangan syariah dianggap sebagai pasar dimana pelaku ekonomi menghindari berurusan dengan kepentingan pribadi, tetapi elemen sistem yang etis dan bertanggung jawab secara sosial sering diabaikan dan atau tidak dipahami dengan baik. Fitur pelarangan bunga dapat dengan sendirinya menarik beberapa investor non-Muslim yang menentang penggunaan hutang dan leverage secara berlebihan. Aspek sosial dari instrumen keuangan syariah dapat menarik perhatian pasar SRI karena alasan berikut:

1. Pendekatan Islam terhadap tanggung jawab sosial memiliki dua aspek. Salah satu aspeknya adalah dengan melarang kegiatan yang dianggap merusak masyarakat dan tatanan sosial, sedangkan aspek lainnya adalah dengan memerintahkan manusia untuk melakukan kegiatan yang mempromosikan keadilan ekonomi dan memastikan perlindungan hak-hak masyarakat yang kurang beruntung. Mengikuti prinsip-prinsip ini, keuangan Islam akan menghindar dari pembiayaan bisnis apa pun yang terlibat dengan aktivitas seperti perjudian, pornografi, produksi alkohol, dan bisnis tidak etis lainnya. Di sisi lain, keuangan Islam akan mendorong pendanaan bisnis yang terlibat dalam praktik ramah lingkungan dan perilaku tanggung jawab sosial.

2. Penekanan Islam pada pengembangan 
sistem keuangan inklusif yang lebih inklusif dan peningkatan akses terhadap keuangan akan mendorong peningkatan sistem keuangan yang lebih efektif. Instrumen distribusi dan distribusi ulang Islam akan memberikan pembiayaan yang hemat biaya kepada masyarakat miskin sehingga mereka mendapatkan kesempatan yang adil untuk berpartisipasi dalam kegiatan ekonomi dan dengan demikian berkontribusi terhadap pembangunan ekonomi (Mohieldin et al., 2011 dalam Bennett dan Iqbal, 2013).

3. Keuangan Islam memberi penekanan besar pada pelestarian hak semua pemangku kepentingan suatu bisnis. Berdasarkan prinsip-prinsip hak dan kontrak hak-hak Islam, pemangku kepentingan yang memiliki kesepakatan kontrak implisit atau eksplisit dengan bisnis dapat memengaruhi pengambilan keputusan. Sebagai pemangku kepentingan yang sentris berlawanan dengan struktur tata kelola pemegang saham, bisnis akan sadar akan hak dan kewajiban pemangku kepentingan apakah pemangku kepentingan adalah karyawan, pelanggan, masyarakat lokal, atau lingkungan.

Salah satu perkembangan terakhir yang paling penting dalam investasi berkonsep SRI yaitu konsep SRI telah beralih untuk secara aktif mencari dan mendukung

beberapa jenis kegiatan dengan uang investasi mereka, dibandingkan dengan mengandalkan "negative screening". Dengan kata lain, lebih banyak investor SRI mencari cara untuk secara aktif mempromosikan perubahan sosial melalui investasi dalam kegiatan dan industri yang mereka dukung daripada menghindari investasi di industri yang tidak memenuhi standar mereka. Keuangan Islam juga secara tradisional sangat bergantung pada “negative screening”.Dana ekuitas yang sesuai dengan syariah, misalnya, telah tumbuh secara signifikan melalui penyaringan dan penyaringan stok bisnis yang dianggap tidak etis dan tidak memiliki kesejahteraan sosial, seperti perjudian dan alkohol.Demikian juga di sisi pendapatan tetap pasar, "negative screening" telah menjadi strategi pra-dominan (yang dalam kasus pendapatan tetap berarti terutama menyaring produk untuk pembayaran yang mewakili kepentingan). Sementara "negative screening" memastikan investor yang mematuhi Syariah bahwa uang mereka tidak akan mendukung kegiatan atau struktur yang dilarang oleh agama mereka, para investor ini belum diberi banyak kesempatan untuk secara afirmatif mendukung kegiatan yang mereka percaya melalui investasi mereka.

\section{Etichal dan Socially Responsibility Investing}




\section{JURNAL NOMINAL / VOLUME VIII NOMOR 2 / TAHUN 2019}

Investasi etis dan bertanggung jawab sosial biasanya mengacu pada proses yang sama dan digunakan secara bergantian dalam literatur. Kedua istilah tersebut menangkap penggabungan pertimbangan "non-financial" atau "extra financial" ke dalam proses pengambilan keputusan investasi. Pertimbangan seperti itu biasanya adalah masalah lingkungan, sosial atau pemerintahan (ESG), namun pada prinsipnya dapat menjadi sesuatu yang investor individu anggap penting, karena apa yang dianggap etis sangat subjektif. Socially Responsibility adalah istilah yang paling umum di AS, sementara investasi etis lebih merupakan istilah Eropa (Hancock, 2002 dalam Traaseth dan Framstad, 2016). Investasi etis adalah pendekatan untuk investasi yang didorong oleh sistem nilai dari pengambil keputusan investasi utama. (Hudson, 2006 dalam Traaseth dan Framstad, 2016).

\section{Teori Prospek}

Teori prospek adalah teori ekonomi perilaku yang menggambarkan caraseseorang memilih antara alternatif probabilitas yang melibatkan risiko, dimana probabilitas keuntungan diketahui.Teori tersebut menyatakan bahwa seseorang membuat keputusan berdasarkan nilai potensi kerugian dan keuntungan daripada hasil akhir.Seseorang mengevaluasi kerugian dan keuntungan ini dengan menggunakan heuristik tertentu. (Kahneman dan Tvrsky, 1979)

Heuristik adalah aturan sederhana dan efisien yang sering digunakan orang untuk membentuk penilaian dan membuat keputusan. Heuristik adalah jalan pintas mental yang biasanya melibatkan fokus pada satu aspek dari masalah yang kompleks dan mengabaikan aspek yang lain. Aturan-aturan ini bekerja dengan baik dalam kebanyakan keadaan, namun bisa menyebabkan penyimpangan sistematis dari logika, probabilitas atau teori pilihan rasional. Kesalahan yang dihasilkan disebut "bias kognitif" dan berbagai jenis telah didokumentasikan. Hal ini telah terbukti mempengaruhi pilihan orang-orang dalam situasi seperti menilai rumah, menentukan hasil dari kasus hukum, atau membuat keputusan investasi. Heuristik biasanya mengatur penilaian otomatis dan intuitif namun juga dapat digunakan sebagai strategi mental yang disengaja ketika bekerja dari informasi yang terbatas.

\section{Pengembangan Hipotesis}

Saat ini perkembangan bisnis perusahaan dipandang masyarakat sebagai faktor utama yang mempengaruhi masalah sosial, lingkungan, dan ekonomi. Kasuskasus skandal perusahaan menyebabkan investor mempertimbangkan kualitas tata kelola dan tanggung jawab yang dilakukan perusahaan (Gupta et all 2013). Berkaitan dengan hal ini, investor menjadi semakin 
sadar pentingnya evaluasi atas pengalokasian aset berdasarkan sustainable (keberlanjutan) dan responsible (tanggung jawab). Istilah SRI merujuk kepada proses investasi yang sejalan dengan analisis keuangan tradisional yang mengintegrasikan analisis terkait tanggung jawab sosial perusahaan dalam rangka mencari peningkatan keuntungan jangka panjang. SRI memberikan suatu cara komprehensif untuk menilai nilai wajar perusahaan dengan cara mempertimbangkan ukuran baik tanggung jawab sosial maupun sustainability perusahaan. (EUROSIF, 2012)

Pendekatan investasi dengan strategi SRI menarik perhatian sejumlah investor yang berharap investasinya sejalan dengan prinsip moral. SRI memasukkan satu atau lebih strategi dalam rangka menyeleksi portofolio atas perusahaanperusahaan yang membahayakan (dikenal dengan "negative screening") dan sekaligus melakukan positive screening dalam rangka mengidentifikasi perusahaan yang memiliki reputasi yang baik.

Investasi pada saham syariah di pasar modal tujuannya untuk mencapai falah dengan tidak melanggar larangan dalam muamalah Islam. Larangan tersebut meliputi unsur riba, gharar, al maisyrr, tidak etis, tidak bermoral juga termasuk tidak diperbolehkan short selling maupun insider trading. Short selling hanya dilakukan dalam kondisi terpaksa, yakni saham harus dijual kepada pihak lain namun bukan sebagai tujuan utama untuk mendapatkan capital gain. Equity premium pada saham syariah yang diperolehnya dari capital gain tentu akan berbeda karena banyak larangan yang dipatuhi terutama short selling sehingga akan menjadi lebih kecil dibanding investasi dalam saham konvensional. (Basri, 2014)

Beberapa literatur ekonomi mengungkapkan bahwa kebanyakan investasi yang menganut prinsip seleksi tertentu seperti Islamic mutual fund memiliki return yang diharapkan lebih rendah dibandingkan investasi yang tidak melalui proses seleksi (Langbein dan Posner, 1980 ; Rudd, 1981; Temper, 1991; Johnson dan Neave, 1996 dalam Bousalam dan Hamzaoui, 2016) dan tingkat diversifikasi yang relatif rendah yang berakibat pada risiko yang lebih tinggi. Lebih lanjut, investasi yang melalui proses seleksi juga dipersepsikan menyebabkan biaya administrasi dan pengawasan yang tinggi. Menurut BinMahfouz dan Hassan (2013) kinerja investasi syahriah bergantung pada wilayah geografis dimana penelitian dilakukan. Sebagai contoh Hoepner el all (2009) dalam BinMahfouz dan Hassan (2013) menemukan bahwa pada umumnya reksa dana saham syariah memiliki kinerja yang tidak berbeda secara signifikan dengan indeks saham 
konvensional secara internasional jika negara asal penelitian memiliki konsumen Muslim dalam jumlah yang besar. Namun, sebaliknya pada negara-negara NonMuslim, reksa dana saham syariah cenderung berkinerja lebih rendah dibanding dengan kinerja pasar.

$\mathrm{H}_{1}$ : Terdapat perbedaan antara return SRIKEHATI dengan IHSG

$\mathrm{H}_{2}$ : Terdapat perbedaan antara return JII dengan IHSG

$\mathrm{H}_{3}$ : Terdapat perbedaan antara return SRIKEHATI dengan JII

$\mathrm{H}_{4}$ : Terdapat perbedaan antara risiko SRIKEHATI dengan IHSG

$\mathrm{H}_{5}$ : Terdapat perbedaan antara risiko JII dengan IHSG

$\mathrm{H}_{6}$ : Terdapat perbedaan antara risiko SRIKEHATI dengan JII

\section{METODE PENELITIAN}

Jenis penelitian ini adalah penelitian komparatif. Penelitian ini bertujuan membandingkan kinerja saham (diproksi dengan return dan risiko) SRI-KEHATI dan JII dengan IHSG sebagai indeks pasar.Jenis data penelitian ini termasuk ke dalam data sekunder. Data-data yang digunakan pada penelitian ini adalah data harian indeks SRI-KEHATI, JII, dan IHSG yang diperoleh dari idx statistic yearly selama periode 2010 sampai dengan 2016.Metode pengumpulan data dengan menggunakan teknik dokumentasi. Data tersebut dapat berupa informasi atau laporan dari Bursa Efek Indonesia maupun dari websitewww.idx.co.id dan www.ticmi.co.id. Variabel yang digunakan dalam penelitian ini adalah kinerja indeks yang diproksikan dengan return realisasi menggunakan pendekatan raw returns.

Selain menggunakan return realisasi sebagai proksi kinerja indeks, penelitian ini juga menggunakan risiko sebagai proksi kinerja indeks. Adapun risiko indeks diukur dengan standar deviasi.

Analisis deskriptif digunakan untuk mengetahui nilai-nilai statistik variabel penelitian yang digunakan dalam penelitian ini. Nilai-nilai statistik seperti mean, standar deviasi return dan risiko IHSG, JII, dan SRI-KEHATI pada periode penelitian akan dibahas pada analisis deskriptif.Pengujian hipotesis dalam penelitian ini menggunakan uji-t yaitu independent t-testmenggunakan tingkat signifikansi sebesar 5\%.

\section{HASIL DAN PEMBAHASAN}

\section{Analisis Deskriptif}

Tabel 2

Return dan Risiko IHSG, JII, dan SRI-

KEHATI

\begin{tabular}{ccccc}
\hline \multirow{2}{*}{ Indeks } & \multicolumn{2}{c}{ Return } & \multicolumn{2}{c}{ Risiko } \\
\cline { 2 - 5 } & $\begin{array}{c}\text { Rata- } \\
\text { Rata }\end{array}$ & $\begin{array}{c}\text { Deviasi } \\
\text { Standar }\end{array}$ & $\begin{array}{c}\text { Rata- } \\
\text { Rata }\end{array}$ & $\begin{array}{c}\text { Deviasi } \\
\text { Standar }\end{array}$ \\
\hline \multirow{2}{*}{ IHSG } & 0,009 & 0,04294 & 0,010 & 0,005039 \\
& 72814 & 1628 & 23690 & 764 \\
\hline \multirow{2}{*}{ JII } & 0,007 & 0,04430 & 0,012 & 0,005771 \\
& 05745 & 2040 & 64286 & 602 \\
\hline
\end{tabular}




\begin{tabular}{ccccc}
\hline SRI- & 0,010 & 0,04725 & 0,012 & 0,005581 \\
$\begin{array}{c}\text { KEHAT } \\
\text { I }\end{array}$ & 08857 & 4857 & 68654 & 029 \\
\hline
\end{tabular}

Sumber : data diolah

Tabel 2 memperlihatkan bahwa returndan risiko tertinggi pada periode penelitian diperoleh dari saham perusahaan-perusahaan yang termasuk dalam indeks SRI-KEHATI masingmasing yaitu returnsebesar 0,01008857 $(1,01 \%)$ per bulan dan risiko sebesar $0,01268654(1,27 \%)$ per bulan. Retun terendah merupakan return dari Jakarta Islamic Index (JII) yaitu sebesar $0,00705745(0,71 \%)$ per bulan. Meskipun memiliki return terendah, risiko saham perusahaan JII memiliki nilai lebih tinggi dibandingkan risiko pasar (IHSG) yaitu 0,01264286 (1,26\%) (dibandingkan risiko pasar (IHSG) yaitu sebesar 0,01023690 $(1,02 \%))$. Dilihat dari nilai standar deviasi, return SRI-KEHATI memiliki nilai penyimpangan yang tertinggi yaitu sebesar 0,047254857 (4,73\%), sedangkan pada risiko saham terlihat bahwa risiko saham JII yang memiliki nilai penyimpangan tertinggi yaitu sebesar 0,005771602 $(0,58 \%)$.

\section{Pengujian Hipotesis}

Tabel 3

Pengujian Normalitas Data

\begin{tabular}{cc}
\hline Variabel & $\begin{array}{c}\text { Signifikansi K- } \\
\text { S }\end{array}$ \\
\hline Return IHSG & 0,205 \\
\hline Return JII & 0,543 \\
\hline Return SRI-KEHATI & 0,554 \\
\hline
\end{tabular}

\begin{tabular}{cc}
\hline Log Risiko IHSG & 0,283 \\
\hline Log Risiko JII & 0,258 \\
\hline $\begin{array}{c}\text { Log Risiko SRI- } \\
\text { KEHATI }\end{array}$ & 0,600 \\
\hline & Sumber : data diolah
\end{tabular}

Hasil pengujian normalitas data, sebagai asumsi yang harus terpenuhi pada pengujian parametrik, menunjukkan bahwa normalitas data return baik return IHSG, return Jakarta Islamic Index (JII), dan return SRI-KEHATI sudah terdistribusi normal. Sedangkan hasil pengujian normalitas data pada data risiko, baik risiko IHSG, Jakarta Islamic Index (JII), dan SRIKEHATI belum terdistribusi secara normal. Oleh karena itu, untuk data risiko dilakukan transformasi data menjadi logaritma, setelah ditransformasi maka asumsi normalitas data sudah terpenuhi (dapat dilihat pada Tabel 3)

Tabel 4

Hasil Uji Beda Antara Return IHSG, Return JII, dan Return SRI-KEHATI

\begin{tabular}{ccc}
\hline Pengujian & $\begin{array}{c}\text { Signifikansi } \\
\text { Levene's } \\
\text { Test }\end{array}$ & $\begin{array}{c}\text { Signifikansi } \\
\mathrm{t}\end{array}$ \\
\hline Return & 0,546 & 0,692 \\
IHSG - JII & & 0,959 \\
\hline Return & 0,248 & \\
IHSG - & & \\
SRI- & & 0,669 \\
KEHATI & & \\
\hline Return JII & 0,563 & \\
- SRI- & & \\
KEHATI & & \\
\hline
\end{tabular}

Sumber : data diolah

Tabel 4 menunjukkan hasil uji beda antara return IHSG, return JII, dan return SRI-KEHATI. Terlihat hasil 
signifikansi Levene's Test pada ketiga pengujian menunjukkan nilai $>0,05$ maka dapat disimpulkan kedua sampel (indeks) memiliki variance yang berbeda diantara dua populasi pada ketiga pengujian hipotesis. Pada pengujian pertama yaitu uji beda antara return IHSG dengan return SRI-KEHATI memiliki nilai signifikansi > 0,05 sehingga dapat disimpulkan bahwa tidak terdapat perbedaan return IHSG dengan return SRI-KEHATI $\left(\mathrm{H}_{1}\right.$ tidak terdukung). Pada pengujian kedua yaitu uji beda antara return IHSG dengan return JII memiliki nilai signifikansi $>0,05$ sehingga dapat disimpulkan bahwa tidak terdapat perbedaan return IHSG dengan return $\mathrm{JII}\left(\mathrm{H}_{2}\right.$ tidak terdukung). Pada pengujian ketiga yaitu uji beda antara return JII dengan return SRI-KEHATI juga memiliki nilai signifikansi $>0,05$ sehingga dapat disimpulkan bahwa tidak terdapat perbedaan return JII dengan return SRIKEHATI ( $\mathrm{H}_{3}$ tidak terdukung).

Tabel 5

Hasil Uji Beda Antara Risiko IHSG, Risiko JII, dan Risiko SRI-KEHATI

\begin{tabular}{ccc}
\hline Pengujian & $\begin{array}{c}\text { Signifikansi } \\
\text { Levene's } \\
\text { Test }\end{array}$ & $\begin{array}{c}\text { Signifikansi } \\
\mathrm{t}\end{array}$ \\
\hline Risiko & 0,572 & 0,001 \\
IHSG - JII & & \\
\hline Risiko & 0,723 & 0,000 \\
IHSG - & & \\
SRI- & & \\
KEHATI & & \\
\hline
\end{tabular}

\begin{tabular}{lll}
\hline $\begin{array}{l}\text { Risiko JII } \\
\text { - SRI- }\end{array}$ & 0,809 & 0,905 \\
KEHATI & & \\
\hline
\end{tabular}

Sumber : data diolah

Tabel 5menunjukkan hasil uji beda antara risiko IHSG, risiko JII, dan risiko SRI-KEHATI. Terlihat hasil signifikansi Levene's Test pada ketiga pengujian menunjukkan nilai $>0,05$ maka dapat disimpulkan kedua sampel memiliki variance yang berbeda diantara dua populasi pada ketiga pengujian hipotesis. Pada pengujian keempat yaitu uji beda antara risiko IHSG dengan risiko SRIKEHATI memiliki nilai signifikansi $<0,05$ sehingga dapat disimpulkan bahwa terdapat perbedaan risiko IHSG dengan risiko SRIKEHATI ( $\mathrm{H}_{4}$ terdukung). Pada pengujian kelima yaitu uji beda antara risiko IHSG dengan risiko JII memiliki nilai signifikansi $<0,05$ sehingga dapat disimpulkan bahwa terdapat perbedaan risiko IHSG dengan risiko $\mathrm{JII}\left(\mathrm{H}_{5}\right.$ terdukung). Pada pengujian keenam yaitu uji beda antara risiko JII dengan risiko SRI-KEHATI memiliki nilai signifikansi $>0,05$ sehingga dapat disimpulkan bahwa tidak terdapat perbedaan risiko JII dengan risiko SRIKEHATI ( $\mathrm{H}_{6}$ tidak terdukung).

\section{Pembahasan}

Tujuan penelitian ini adalah untuk menguji secara empiris keterkaitan konsep investasi berwawasan tanggung jawab sosial (Social Responsible Investing) dan 


\section{JURNAL NOMINAL / VOLUME VIII NOMOR 2 / TAHUN 2019}

kinerja saham, di mana diduga bahwa proses positive screening dan negative screening dari SRI akan mengarahkan investor pada pilihan-pilihan saham perusahaan yang memiliki reputasi baik dan memiliki kepastian sustainable terkait operasional perusahaan di masa mendatang berdasarkan prinsip tertentu sehingga diduga bahwa kinerja saham perusahaan yang menerapkan konsep SRI (JII dan Indeks SRI-KEHATI) relatif lebih tinggi daripada kinerja saham konvensional atau pasar (IHSG). Kinerja masing-masing indeks pada penelitian ini diukur dari return dan risiko. Hasil pengujian normalitas data, baik return dan risiko masing-masing indeks menunjukkan bahwa data-data terdistribusi normal sehingga pengujian terkait dengan perbedaan kinerja IHSG, JII, dan Indeks SRI-KEHATI dilakukan dengan menggunakan pengujian parametrik, dalam hal ini menggunakan independent t-test.

Hasil pengujian menggunakan independent t-test menunjukkan bahwa berdasarkan perbandingan kinerja indeks dari sisi return ditemukan bahwa tidak terdapat perbedaan return yang signifikan baik antara IHSG dan Indeks SRIKEHATI, IHSG dan JII, maupun Indeks SRI-KEHATI dan JII. Hasil ini menunjukkan bahwa baik IHSG, Indeks SRI-KEHATI, dan JII memiliki kinerja yang relatif merata di mana tidak ada Indeks yang return-nya lebih mendominasi (lebih tinggi) indeks yang lainnya. Hasil penelitian ini berbeda dengan hasil penelitian Wang (2011), Diaz (2016), BinMahfouz dan Hassan (2013), serta Bousalam dan Hamzaouli (2016).Adapun hasil ini mengimplikasikan bahwa investor menjadikan baik kinerja IHSG, JII, dan SRI-KEHATI sebagai pedoman untuk mengambil keputusan investasi. Adapun belum terlalu signifikannya kinerja JII dan SRI-KEHATI mungkin disebabkan karena masih relatif rendahnya tingkat penguasaan pasar (market capitalization) perusahaanperusahaan yang terdaftar dalam indeks tersebut di mana penguasaaan pasar masih di bawah 50\% (JII sebesar 35\% dan SRIKEHATI sebesar 46,5\%). Indeks LQ45 masih mendominasi penguasaan pasar modal di BEI di mana market capitalization sebesar $65 \%$.

Adapun hasil pegujian berdasarkan perbandingan kinerja indeks dari sisi risiko ditemukan bahwa terdapat perbedaan risiko yang signifikan baik antara IHSG dan Indeks SRI-KEHATI maupun antara IHSG dan JII.Sementara itu, tidak ditemukan adanya perbedaan risiko yang signifikan antara JII dan Indeks SRIKEHATI.Secara spesifik, hasil pengujian menunjukkan bahwa dari sisi risiko, risiko IHSG relatif lebih rendah dibandingkan dengan JII dan Indeks SRI-KEHATI. Hasil penelitian ini sejalan dengan penelitian Basri (2014) serta Bousalam dan 
Hamzaouli (2016) yang menemukan bahwa saham syariah memiliki spread yang lebih besar atau cenderung lebih berfluktuatif. Diversifikasi risiko pada IHSG nampaknya lebih efektif dibandingkan dengan diversifikasi risiko pada JII dan Indeks SRIKEHATI.Hal ini dapat dilihat baik dari sebaran subsektor industri maupun penguasaan pasar dari masing-masing Indeks.Jumlah kategori industri di BEI berdasarkan Jakarta Stock Industry Classification (JASICA) adalah sebanyak 9 kategori industri dengan total 48 subsektor industri. Terlihat bahwa jumlah sebaran subsektor industri pada JII dan Indeks SRIKEHATI hanya sebanyak 17 subsektor industri atau hanya sebesar $35 \%$ dari keseluruhan subsektor industri di BEI. Jumlah ini jauh lebih kecil apabila dibandingkan dengan jumlah sebaran subsektor industri di Indeks LQ45, yaitu sebanyak 24 subsektor industri atau 50\% dari keseluruhan subsektor industri di BEI. Adapun tingkat penguasaan pasar (market capitalization) perusahaan-perusahaan yang terdaftar dalam JII dan Indeks SRIKEHATI masih di bawah 50\% (JII sebesar $35 \%$ dan SRI-KEHATI sebesar 46,5\%). Indeks LQ45 masih mendominasi penguasaan pasar modal di BEI di mana market capitalization sebesar $65 \%$. Hal ini menyebabkan efektifitas upaya (insentif) untuk melakukan diversifikasi portofolio pada JII dan Indeks SRI-KEHATI masih relatif rendah.Risiko IHSG massif relatif lebih rendah (stabil) dikarena upaya (insentif) melakukan diversifikasi pada portofolio asset relatif lebih tinggi.

\section{DAFTAR PUSTAKA}

Basri. (2014). Perbandingan Kinerja Saham Syariah Dan Saham Konvensional Di Bursa Efek Indonesia (Studi Kasus Tahun 2013). EFEKTIF Jurnal Bisnis dan Akuntansi. Vol.5. No.2 Desember 2014, hal. 127-147.

Bennett, Michael.S. dan Zamir Iqbal. 2013. How Socially Responsible Investing Can Help Bridge The Gap Between Islamic And Conventional financial Markets. International Journal of Islamic and Middle Eastern Finance and Management ; Bingley 6.3 (2013), hal. 211-225.

BinMahfouz, Saeed dan M. Kabir Hassan. 2013. Sustainable and Socially Responsible Investing : Does Islamic Investing Make A Difference?. Humanomics. Vol. 29. Issue : 3. Pp 164-186. DOI : 10.1108/H-07-2013-0043.

Bousalam, Issam dan Moustapha Hamzaoui. 2016. Impact of Ethical Screening on Risk and Returns : The Case of Constructed Moroccan Islamic Stock Indices. Journal of Financial Regulation and Compliance. Vol. 24. Issue : 3. Pp : 268-291. DOI : 10.1108/JFRC-012016-0002.

Bratenius, Anna Linnea Helena dan Emelie Josefin Melin. 2015. The Impact of CSR on Financial Performance (An Event Study Of Abnormal Stock Returns Of Swedish Companies As A Reaction To The Release Of The Folksam Index Of Corporate Social Responsibility). Master Thesis M.Sc. Accounting Strategy \& 
Control Copenhagen Business School.

Diaz, John Francis. T.. 2016. Return And Volatility Performance Comparison Of Ethical And Non-Ethical Publicly-Listed Financial Services Companies. Ethics and Economics 13 (1). http://ethiqueeconomique.net/

Kahneman, Daniel dan Amos Tversky. 1979. Pospect Theory : An Analysis of Decision Under Risk. Econometrica. Vol. 47. No. 2. Pp : 263-292.

Karim, Khendkar, Sanghyun Suh dan Jiali Tang. 2016. Do Ethical Firms Create Value?. Social Responsibility Journal. Vol.12. Issue : 1. Pp : 54-68. DOI : 10.1108/SRJ-09-2014-0127.

Randina, Teuku Muhammad dan Fachrizal. 2016. Analisis Perbandingan Kinerja Keuangan, Abnormal
Return Dan Volume Perdagangan Saham Antara Periode Sebelum Dan Sesudah Meraih Indonesia Sustainability Reporting Award (ISRA). Jurnal Ilmiah Mahasiswa Ekonomi Akuntansi (JIMEKA). Vol.1. No. 2, hal : 71-83.

Traaseth, Anders Johan Rustestuen dan Ulrik Elstad Framstad. 2016. Ethical Investing-A Study of Performance. Master Thesis, M.Sc. Economics and Business Administration, Finance and Investment Copenhagen Business School.

Wang, Yungchin George. 2011. Corporate Social Responsibility and Stock Performance-Evidence From Taiwan. Modern Economy. Vol. 2. No. 5. Pp : 788-799. DOI : 10.42361/ME.2011.25087.

http://www.kehati.or.id/indeks-sri kehati/diakses tanggal 20 Mei 2017. 